\title{
Implications of Work Choices Legislation
}

\section{Mark Wooden}

$\mathrm{I}$ $\mathrm{t}$ is widely recognized that the character of Australia's industrial relations systems and institutions have changed dramatically over the last two decades. Most obviously, wages and employment conditions are no longer so dependent on arbitrated awards and instead are much more likely to be the product of enterprise and workplace bargaining (Wooden, 2000). But despite the major changes that have occurred, the current Coalition Government has long made it clear that, in its view, the reform agenda was far from complete and that not for a hostile Senate, further change could have been expected. The opportunity to press ahead with this agenda was thus delivered at the 2004 federal election when the Coalition, unexpectedly, won control of the Senate.

Following the election victory the government began developing a program of legislative reforms intended to facilitate what the Prime Minister, in a statement to parliament on 26 May 2005, described as 'the modernisation of Australia's workplace relations system'. More specifically, the stated aim was to bring about a simpler workplace relations system that provided greater primacy to the making of agreements at the workplace level. In the PM's view, such a system would result in 'high productivity, increasing real wages, choice and flexibility'.

The centrepiece of that legislative reform program, the Workplace Relations Amendment (Work Choices) Act 2005 (from hereon referred to simply as 'Work Choices'), has drawn highly vociferous responses from many quarters of Australian society. Predictably, it has attracted favourable responses from employer organizations and hostile reactions from the trade union movement. The Australian Chamber of Commerce and Industry (ACCI, 2005:5), for example, described it as an 'historic step forward for Australia' and predicted that 'the reforms should kickstart another round of productivity growth' which ultimately will mean more jobs and higher real wages. In contrast, the position of the Australian Council of Trade Unions (ACTU) is that workers will be far worse off. According to ACTU President, Sharan Burrow: 'The clear goal of the Government's new workplace law is to boost the profits of big business at the expense of the basic rights and living standards of working Australians'. She went on to assert that the 'new laws will hurt the most vulnerable workers and reduce the job security and living standards of all Australian workers and their families' (ACTU, 2005). The ACTU position is also one that appears to be shared by a large number, if not the majority, of industrial relations academics in this country. For example, in a submission to the Senate Inquiry into the Work Choices Bill, a Group of 151 Australian Industrial Relations, Labour Market, and Legal Academics (2005:43) claimed that the proposed legislation will 'have no direct

Mark Wooden is Professorial Fellow and Deputy Director of the Melbourne Institute of Applied Economic and Social Research, University of Melbourne. 
positive impact on productivity and, through it, wages or employment growth' and instead 'will contravene long established international labour standards, strengthen employer prerogative, create new hazards for many working Australians, widen inequality and disadvantage the most vulnerable'.

The aim of this paper is to briefly review this debate. The paper begins with an overview of the Work Choices Act. It then turns to a discussion of how these changes might (or might not) impact on employment and productivity.

\section{The Work Choices Act: The Key Elements}

While the legislation is very complicated, lengthy (the Act runs to over 750 pages), and seemingly affects in some way almost every aspect of the previous legislation, the major reforms implemented can be distilled to quite a short list, the most prominent of which are briefly described below.

- Creation of a national labour law system based on the corporations power in the constitution. Essentially all employees of constitutional corporations will be covered by the Workplace Relations Act 1996, leaving only employees of unincorporated businesses and state governments to be covered by the state systems (thought to be around 15 per cent of all employees in Australia).

- Creation of a new body - the Australian Fair Pay Commission responsible for establishing and varying the federal minimum wage, all other wages specified in awards, and casual pay loadings.

- Abolition of the no-disadvantage test and its replacement by the Australian Fair Pay and Conditions Standard covering just five basic conditions award rates of pay, maximum ordinary hours of work, annual leave, personal and carers leave, and parental leave. These five conditions will be the only award conditions which cannot be varied or excluded in a workplace agreement. Further, in the event of the termination of an agreement it is these five minimum conditions that the parties fall back to.

- Major changes in the nature and operation of federal awards. Included here are: rationalization of the current award structure; further reduction in the number of allowable matters; and restricting the ability of the Australian Industrial Relations Commission (AIRC) to vary awards to cases where such variation is justified on rationalization, simplification or minimum award safety net grounds.

- With the exception of the five minimum conditions, workplace agreements will replace all award conditions that otherwise would apply to the workers covered by these agreements. Registered individual agreements (that is, Australian Workplace Agreements, or AWAs) will also take precedence over collective agreements, even if those collective agreements are currently in operation.

- A much simpler approval process for agreements, with all agreements, both collective and individual, needing only to be lodged with the Office of the Employment Advocate (OEA) to take effect. Financial penalties, however, 
will be incurred by employers if any breaches in the agreement-making process are reported and proven. Examples include: failure to provide a copy of the proposed agreement to employees at the beginning of the 'consideration period'; failure to secure approval for the agreement from a valid majority of employees (if a collective agreement) or from the employee concerned (if an AWA); failure to lodge the agreement with the OEA within 14 days of approval being obtained from employees; and lodging an agreement with prohibited content (for example, clauses which restrict the use of contractors or provide redress for unfair dismissal).

- Significant changes to the way unfair dismissal laws operate. Most noticeably, all firms with 100 or fewer employees will be exempt from the operation of unfair dismissal laws. Furthermore, for employees of larger employers there will be a 6-month qualifying period and any dismissal on the grounds of 'operational requirements' will not be covered by these laws.

- A significantly reduced role for the AIRC. As already noted, the AIRC will no longer have responsibility for setting and varying award wages and its discretion to vary other conditions in awards will be severely curtailed. The AIRC will continue to have a potentially important role in the settling of disputes, but even then all parties to the dispute must agree to the involvement of the AIRC.

- Stronger laws in relation to industrial action. Included here are: providing quicker remedies for unprotected action; requiring secret ballots to be held before any protected action can be taken; requiring the AIRC to order that any unlawful action stop; the prohibition of all industrial action during the term of an agreement; and providing the Minister the power to terminate a bargaining period if industrial action is threatening significant damage to the economy.

- $\quad$ Tighter rules governing rights of entry by trade unions to workplaces.

\section{Employment Consequences}

One of the major claims of the government is that Work Choices will help create jobs. This might occur via restraining the rate of growth in wage costs, reducing other non-wage labour costs, and second-round output effects. The discussion to follow focuses on the possible impacts of a change in minimum wage setting institutions and in the reduction in firing costs arising from changes in unfair dismissal laws. Work Choices, however, will also affect bargained outcomes for some workers on above award wages. Indeed, it is often claimed that under the new regime individual agreements will be far more attractive partly because they make it far easier for employers to reduce wages and other conditions below what was previously obtained via a collective agreement (for example, Peetz, 2005). At this time all we can really say is that some workers will be 'worse off' in terms of pay and conditions under Work Choices. What we cannot predict is how many workers will be so affected. Nevertheless, the certainty that labour costs for at least some over-award employees will be reduced compared with the 
counterfactual makes the possibility of positive output effects even more likely. The section thus concludes with a brief discussion about the channels through which these output effects can be expected to operate.

\section{Minimum wages}

One of the features of Work Choices that has received considerable attention is the transfer of responsibility for setting minimum wages from the AIRC to a new body, the Australian Fair Pay Commission (AFPC), which will report directly to the Minister and operate entirely independently of the AIRC. The widely held presumption is that the government expects the AFPC to deliver lower rates of increase in the minimum wage than would have been delivered by the AIRC, which in turn should promote employment growth among the low-paid.

The expected positive employment response hinges on two assumptions. First, that employment growth of the low skilled is responsive to real wage cuts, and second that the AFPC will deliver different minimum wage outcomes than the AIRC.

The first issue is one that until about a decade or so ago there was relatively little disagreement - the quantity of labour that a firm will hire typically varies inversely with the price of that labour, and so long as there is excess labour (unemployment) any increase in the wage required to be paid will lead to a reduction in the level of employment, though the size of the negative effect was usually judged to be quite small. That consensus seemingly evaporated in the 1990s following the publication of results from a number of so-called natural experiments in the US (see Card and Kruger, 1995). In this body of research teenage employment was actually found to rise in response to minimum wage increases. The debate about the impact of minimum wage increases on employment in North America continues, though few researchers have been able to replicate the finding of a significant positive employment response.

As a guide to likely employment effects in Australia, however, the US debate is of limited relevance. As Hamermesh (1993:191) has noted, if the minimum wage is far to the left in the wage distribution, as it is in the US, then aggregate employment effects will never be large. In Australia, however, the minimum wage is much closer to the middle of the wage distribution. The UK Low Pay Commission (2005:233-241), for example, reported on data for 13 OECD countries for 2004 which showed that relative to full-time median earnings, the adult minimum wage in Australia was higher than for any other country in their list (see Figure 1). As such, changes in minimum wages are likely to affect many more workers and potential workers in this country than in other countries, and especially the US. 
Figure 1: Adult Minimum Wages Relative to Full-time Median Earnings, Mid-2004: OECD Countries

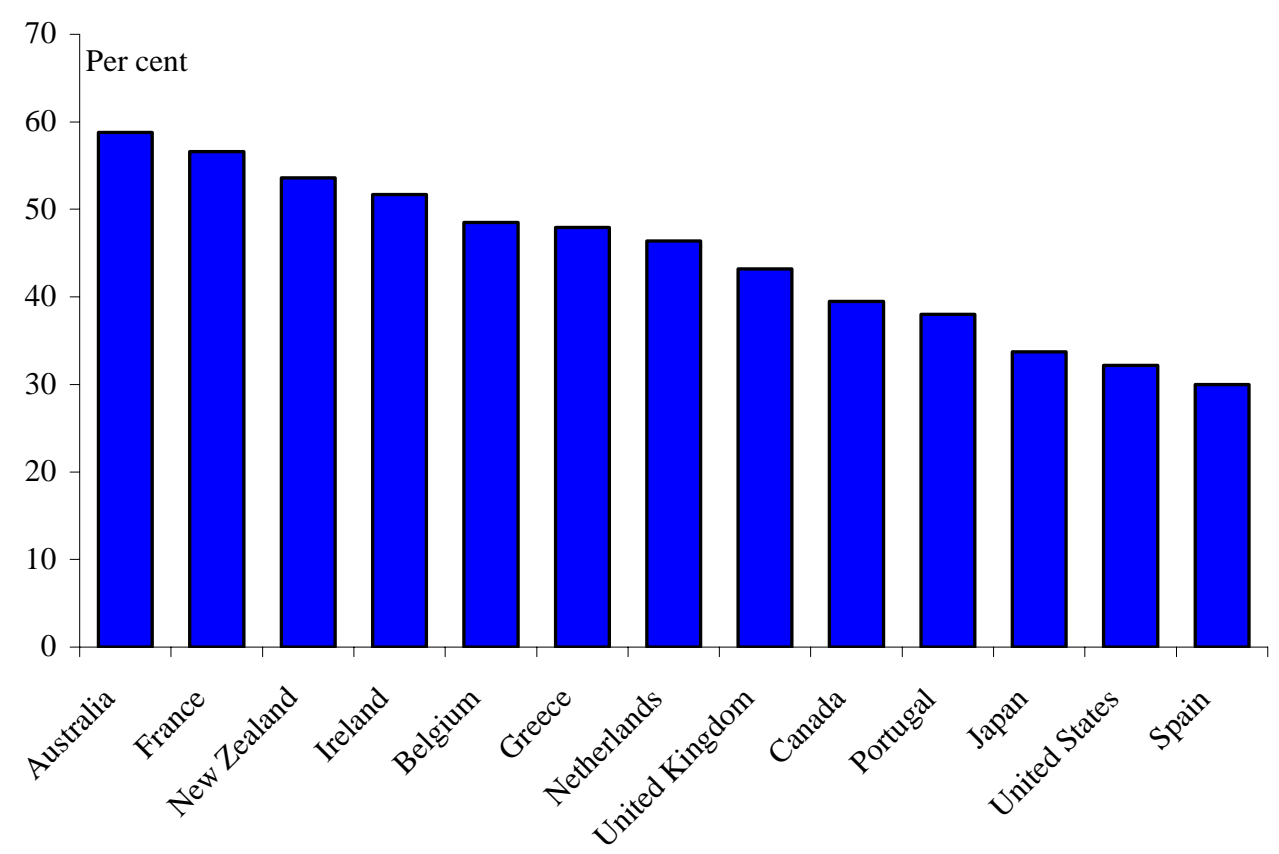

Source: UK Low Pay Commission (2005:237, Table A4.2).

Perhaps Australia would do better to draw on the experience of other countries with relatively high minimum wage levels, such as France. At first glance, however, a review of the evidence from French studies suggests highly mixed findings, with some researchers reporting negative employment effects (Bazen and Skourias, 1997, Abowd et al, 2000) and others unable to detect any significant impacts (for example, Dolado et al, 1996, Machin and Manning, 1997). A key feature of minimum wage setting in France, especially during the 1990s, however, was that government often offset the impact of minimum wage increases on labour costs by offering tax exemptions on payroll taxes targeted on low-wage labour. Empirical research that does not take this into account can thus be expected to understate any employment effects. The importance of this has been demonstrated by Kramarz and Phillippon (2001) who used individual-level longitudinal data from the French Labour Force Survey over the period 1990 to 1998 to compare the effects of changes in minimum total labour costs (the statutory minimum wage plus employer-paid payroll taxes) on workers employed at the minimum wage (the treatment group) with those employed marginally above it (the control group). Their difference-in-difference estimates suggested a very substantial elasticity of demand (-1.5) for minimum wage workers.

Nevertheless, while the relative level of the minimum wage may be similar in Australia and France, that is about as far as the similarity extends. With respect to 
other labour market policies and institutions, the two countries are very different. What is needed are estimates based on Australian data. Unfortunately, there are relatively few studies of the employment impacts of the minimum wage in Australia that can be taken seriously. Both Mangan and Johnston (1999) and Junankar, Waite and Bellchamber (2000) investigated the impact of minimum wages on teenage employment using aggregate time-series data and reported little evidence of any significant detrimental impacts, but neither of these studies provide a credible test. As highlighted by Card and Krueger (1995:183), in the time-series approach the counterfactual is not obvious. It is also not obvious that there were any major variations in the level of minimum award wages over the periods studied. Minimum award wages were generally raised in a fairly predictable fashion, mostly in line with prices, and so would have been factored into the hiring policies of most firms. As a consequence, minimal employment impacts are exactly what would be expected.

The Card and Kruger solution is to identify 'natural experiments' with which to evaluate the impact of minimum wage increases. To date, the only Australian study that has attempted to estimate the effect of minimum wages on employment within a quasi-experimental setting is Leigh (2003; 2004a). He examined six rises in the statutory minimum wage in Western Australia, comparing the differences in employment in Western Australia before and after each rise with differences in employment over the same period in the rest of Australia (the control group). In his corrected results (Leigh, 2004a) the estimated 'minimum wage elasticity' is -0.29 , and this effect rises to about -1 for young people, the group for whom minimum wages have the greatest bite. That is, a one per cent increase in the minimum wage reduces aggregate employment for persons in the 15 to 24 year old age group by one per cent compared with the outcome in the absence of the minimum wage increase.

Leigh's study, while the most important empirical contribution yet to the Australian debate, is not beyond criticism. Indeed, Watson (2004) provides a spirited critique. Most of these criticisms were countered by Leigh (2004b) in his rejoinder. Nevertheless, one of Watson's key claims - that, in the absence of a true experiment, the difference-in-difference approach is unlikely to perfectly control for all relevant influences deserves to be taken seriously. But surely this means that better data will be needed before the different protagonists in this debate can be reconciled; it does not mean rejecting Leigh's research as unhelpful (as Watson does). And even if Leigh's results are rejected, the only conclusion that should be drawn is that we still do not know how large the impact of minimum wage increases is on employment in Australia. The lack of convincing evidence does not mean there is no impact.

Let us assume that the demand for labour is responsive to changes in the real wage, a conclusion that sits well with the considerable empirical evidence on the elasticity of demand for labour (see Webster 2003). Will simply transferring powers from one body responsible for minimum wage setting to another make a difference? This is an issue I have discussed at length elsewhere (Wooden, 2005), so let me jump straight to the answer - a modest difference at best. 
Assume for the moment that the new AFPC decided that it would be appropriate to reduce the real level of the minimum wage to bring it more in line with the levels in most other OECD countries, say something around 45 to 48 per cent of median earnings. Since the AFPC is prevented from reducing any nominal wage rates below their current level, this would effectively mean holding the minimum weekly wage at its current level and letting inflation erode the real value. The idea here of course is that by letting the real value of the minimum wage fall, demand for low-wage workers will be stimulated. Out-of-work benefits, however, are indexed to either prices or average male earnings, and so will continue to rise and eventually the benefits from not working will exceed the benefits from working in a minimum wage job.

Some crude evidence for this is shown in Table 1. This table reports figures on in-work and out-of-work incomes for four types of households. In all cases it has been assumed that the potential earned income is the national minimum wage - \$484.40 per week before tax following the 2005 Safety Net decision - and that there is 100 per cent uptake of all benefit entitlements (it has also been assumed that none of the households are receiving rent assistance). If we focus on the first row we can see that a single person in receipt of unemployment benefits (Newstart Allowance) would be receiving just \$202 per week. If that person were able to secure a minimum wage job, their after-tax income would more than double to $\$ 478$. For this group, and indeed all persons without children, there is a sizeable economic return to employment in a minimum wage job. For people with children the story is quite different. If we take a couple with two children, out-ofwork disposable income per week is calculated to be $\$ 566$ per week. If one adult in the household were then to obtain a full-time minimum wage job their income would rise by 22 per cent to $\$ 692.12$. Once we factor in the costs of working (such as transport costs), the loss of in-kind benefits associated with any loss of concession card entitlements, and the psychic disutility from working, the incentive to work, at least in a short-run static sense, may already be quite low. Holding the real wage constant while allowing benefits to increase in line with the CPI will only further reduce the incentive to work. Given the current structure of the tax transfer system, the AFPC may well find that, unless it wishes to reduce the incentive to work among low-wage workers with children, it will at some time be forced to effectively index the minimum wage to benefit levels.

It might be argued that the incentive problem could be dealt with by withdrawing benefits from any unemployed worker who rejects a job offer at the minimum wage. Indeed, some might argue that the Government is already moving down this path with tighter eligibility requirements for many pensions and benefits, and especially the Parenting Payment, from 1 July 2006. Most of these changes, however, are largely about moving certain groups on to an equal footing with Newstart recipients. Thus parents of children where the youngest has reached six years of age will now have an obligation to seek at least part-time work. An obligation to seek work, however, is very different from an obligation to accept offers of work. More generally, a 'stick' approach offers no real 
solution. A reluctant worker is also likely to be a relatively unproductive worker and thus unlikely to be retained by their new employer for very long.

Table 1: Income Replacement for Minimum Wage Workers, July 2005

\begin{tabular}{l|ccc}
\hline Household type & $\begin{array}{c}\text { Weekly out of work } \\
\text { after tax-income } \\
(\$)\end{array}$ & $\begin{array}{c}\text { Weekly in-work } \\
\text { after-tax income } \\
(\$)\end{array}$ & $\begin{array}{c}\text { Income } \\
\text { replacement rate } \\
(\%)\end{array}$ \\
\hline $\begin{array}{l}\text { Single adult } \\
\text { Couple with 2 children } \\
\text { - one earner }\end{array}$ & 202.55 & 478.30 & 42.3 \\
$\begin{array}{l}\text { Couple with 2 children } \\
\text { - one and a half earners }\end{array}$ & 566.40 & 692.10 & 81.8 \\
$\begin{array}{l}\text { Sole parent with 2 } \\
\text { children }\end{array}$ & 566.40 & 806.40 & 70.0 \\
\hline
\end{tabular}

Source: Figures provided by Guyonne Kalb and derived using the Melbourne Institute Tax and Transfer Simulator.

The AFPC will not only be responsible for the federal minimum wage but also for all other wage rates specified in awards, and here they will be less constrained by the level of out-of-work benefits. Indeed, it is not implausible that the AFPC could decide to leave all award rates above the national minimum unchanged. Workers on award rates above the minimum safety net would thus need to negotiate with their employer to secure wage increases, an outcome highly consistent with the overall objectives of the Work Choices Act. It is impossible to predict the extent to which overall wage costs could be affected, but it seems inconceivable that some, if not many, of these award wage workers would not experience some decline in real wages, at least in the short-term, if the AFPC decided on this course of action. What the AFPC will do, however, is (at the time of writing) unknown.

\section{Unfair dismissal laws}

The access to the jobs market by the unemployed is also hindered by legislation that protects workers from unfair dismissal by employers. Legislation along these lines is common in most Western countries and appears to have widespread social acceptance. Nevertheless, such laws have a number of unintended consequences. Most obviously, by reducing the discretion employers have to dismiss unwanted or unproductive employees, such laws will affect recruitment and selection procedures and decisions. Supporters of employment protection will argue that this is a good thing, with employers encouraged to adopt fairer and more transparent policies for dealing with poor performers. However, for many employers, and especially small employers which lack the resources necessary to both effectively screen and select new employees and to 'manage' employees who fit the business poorly, both the number and type of workers hired are likely to be 
affected. For example, in the presence of laws that make firing more difficult, small businesses might choose to employ greater numbers of workers who would be outside the coverage of these laws or less likely to resort to them in the event of dismissal. This might involve hiring family members or personal friends. Alternatively, it might encourage businesses to use agencies to meet their labour needs or to hire workers on a casual basis (while casual workers were covered by unfair dismissal laws, casual employees are less likely to be aware of their rights or to seek legal redress). Very differently, given the relatively greater risk from making a selection mistake, small employers will tend to be more conservative in their hiring policies and indeed many will choose not to employ any workers at all.

Many, however, would dispute the link between unfair dismissal laws and employment assumed here. Indeed, since an increase in dismissal costs can be expected to reduce both the rate of separations and new hires, it is not obvious that aggregate employment would decline. (Though it is unambiguous that both average job tenure and unemployment duration will lengthen.) Waring and de Ruyter (1999), for example, pointed to the continued rise in the small business share of employment during the 1990s following the introduction of unfair dismissal laws in the federal jurisdiction in the early 1990s as evidence that such laws have not been a barrier to employment growth. Such evidence, however, demonstrates little. Most obviously, most small businesses were covered by State laws and not the federal system, and the existence of unfair dismissal laws in most State jurisdictions dates back to the 1970s. In any case, before and after comparisons tell us nothing about the counterfactual; what we need to know is how employment would have changed in the absence of such laws.

In the absence of a natural experiment we thus have to rely on survey data collected from businesses about the impact of dismissal regulations on business costs. The most often cited example here is Harding (2002) who used results from the responses of a sample of managers at 1800 businesses with fewer than 200 employees to generate an estimate of the cost impost on the Australian economy of unfair dismissal laws. His lower bound estimate is that these laws add an amount equivalent to about 0.2 per cent of the annual Gross Domestic Product to business costs. The impact on jobs is harder to estimate, but based on an assumed elasticity of demand of 0.7 (the long-run wage elasticity of demand in the Treasury Macroeconomic Model), Harding concluded that employment levels are at least about 0.5 per cent lower than they would otherwise be.

Evidence based on essentially qualitative survey evidence, however, is far from ideal. Most obviously, this type of data is open to the criticism that given the climate and context in which the data were being collected, managers may have had a tendency to overstate the impact of unfair dismissal laws on both costs and hiring behaviour. Nevertheless, it needs to be recognized that Harding uses very conservative assumptions in calculating the employment effects. He applies his lower bound estimate of the cost impost and also adopts a conservative estimate of the elasticity of demand. Most importantly, and as made clearer in a subsequent paper (Harding, 2005), he was unable to take into account the additional costs to 
the business associated with having to continue to employ workers who would otherwise have been dismissed.

More recently, Harding's findings have been challenged by other survey evidence collected by Freyens and Oslington (2005). In contrast to Harding, they administered a survey designed only to collect relevant quantitative data. Their findings, based on responses from just over 1400 small and medium enterprises, led them to conclude that any adverse employment impact from unfair dismissal laws is tiny - about 6000 jobs Australia-wide. The emphasis on only collecting directly measurable costs, however, caused them to ignore many important costs. The only costs they measure are those directly incurred by the employer when firing a worker for cause, such as the time spent writing written warnings, obtaining legal advice, gathering evidence and in the conciliation process, and the cost of any settlement payment. But as Harding (2005) has observed, this focus ignores the potentially much larger costs associated with both 'the additional management procedures necessary to reduce unfair dismissal claims' and the impact on output from retaining low productivity workers. In summary, Freyens and Oslington found a trivial employment effect precisely because the costs they measure are also trivial. The true employment impact will be much larger.

It is essentially because of this possible positive employment impact that the Federal Coalition government repeatedly sought exemptions for businesses with 20 or fewer employees from the unfair dismissal law provisions of the Act. Now that it has the mandate to affect change, however, the government has decided to extend this exemption to all businesses employing up to 100 workers. As should be clear from the arguments set out above, laws prohibiting 'harsh, unjust or unreasonable' termination are unlikely to have as much impact on large firms. They typically have the resources and personnel to both avoid recruitment and selection mistakes and to ensure termination is preceded by due process. Restrictions on hiring are only likely to have a sizeable impact on employment decisions in the very small firms. For firms that currently employ no one the direction of effect is clear - reducing employment protection costs can only cause employment to increase. The magnitude of the positive employment effect can then be expected to gradually decline with size. That said, it should be recognized that the presence of other legislation, and most notably antidiscrimination legislation, will rein in some of these effects.

\section{Output effects}

Industrial relations reform might also affect employment outcomes by raising aggregate demand. For example, if the reforms result in lower unit costs, either through lower real labour costs, high productivity, or a combination of both, competition will place downward pressures on prices, which effectively raises real disposable incomes and consumer spending. Some, and notably Peetz (2005), would challenge this. In Peetz's view all of the cost savings will end up accruing to employers as profits, which seems an extreme view given it implies the complete absence of competitive pressures in product markets. In any case, higher 
profitability can promote employment expansion through increased investment, increased taxation revenue or its ameliorating on interest rates.

Very differently, demand can be stimulated through any restraining impact of the reforms on aggregate inflationary pressures. This is likely to occur through two mechanisms. First, a shift towards a more decentralised enterprise bargaining structure has the effect of reducing the rate of flow-on of wage increases from high-productivity firms and sectors to low-productivity ones. Second, any further reductions in union power will reduce the ability of unions to bid wages up above their market level. Evidence supportive of both of these hypotheses can be found in Lye and McDonald (2004; 2005). The estimates of Lye and McDonald (2005) suggest that the decline in union density since the mid-1970s has effectively reduced the 'minimum' equilibrium rate of unemployment by about three percentage points while the effect of the growth in coverage of enterprise agreements during the 1990s was to reduce it by almost one percentage point.

Under the new reforms the expectation is that both union power and influence will be further weakened and bargaining structures will become even more fragmented as increasing numbers of employers opt for individual agreements. Again, the expectation is that this will allow a more expansionary monetary policy setting and potentially higher rates of employment growth.

\section{Agreement-making and Productivity}

Another of the key claims used to justify the Work Choices reforms is that more flexible forms of agreement-making promote productivity growth. Unfortunately, this is an area that is rich in rhetoric but poor in evidence. Loundes, Tseng and Wooden (2003), for example, in their review of the evidence on the link between enterprise bargaining and productivity, concluded that the research needed to either confirm or reject the hypothesis that enterprise bargaining has had a beneficial effect on productivity has not been conducted. While a careful reading of Loundes, Tseng and Wooden (2003) might suggest, on the balance of the evidence reviewed, that the hypothesis is supported, the authors make it very clear that such a strong conclusion would not be warranted. The macroeconomic evidence for example, while consistent with the hypothesis, does not establish causation; case-study research, at best, only highlights the potential for enterprise bargaining to facilitate improved productivity; and the limited micro-econometric studies that have been undertaken have all used data that invariably have proved not well suited to the task. About the only thing we can be certain of is that many managers believe that enterprise agreements (and individual agreements) have been good for workplace performance, which of course is very different from establishing that positive performance consequences actually resulted.

More recently Access Economics (see Ryan, 2005) reported evidence of an inverse relationship across industries between productivity growth and award reliance, something that also featured prominently in the government's Regulation Impact Statement accompanying the Work Choices Bill. But as Peetz (2005) has correctly observed, correlation does not establish causation. Indeed, causation is 
likely to be stronger in the other direction. Productivity growth makes higher rates of wage growth possible which in turn will require over-award pay outcomes.

Under Work Choices the emphasis shifts from enterprise-based bargaining structures to individual-based bargaining structures (and in particular, AWAs), and on this topic — the link between individual agreements and productivity - the research base is even weaker. Nevertheless, this has not prevented commentators on both sides of the debate from making strong claims about the likely links. The government position is well known and is best summarized in its 2004 election policy, 'Flexibility and Productivity in the Workplace: The Key to Jobs'. There it is claimed that AWAs 'raise productivity, efficiency and allow for greater flexibility'. Similar sentiments have been echoed by the Business Council of Australia (2005:12) and in media releases from other employer bodies.

Many industrial relations academics are highly critical of such claims, arguing that the government and its supporters have failed to produce any convincing evidence to support its position. Peetz (2005), however, goes a lot further than simply attacking the evidence used by the government and its supporters, arguing that the 'available evidence indicates that there is no positive relationship between individual contracting and productivity' (p. 51) (emphasis added). The main pieces of evidence that Peetz uses to support this contention are: (i) the much weaker labour productivity growth figures in New Zealand compared with Australia following the introduction of individual contracts in New Zealand in 1991; and (ii) the relatively weak productivity growth in Australia during the most recent productivity cycle (since about 2000). Neither of these pieces of evidence, however, proves much.

It is true that growth in output per worker hour was relatively slow in New Zealand during the early 1990s, but labour productivity on its own is not a good measure of the productivity of the economy. As argued elsewhere (Wooden, 2000:156-158), New Zealand experienced a marked surge in employment following the introduction of the Employment Contracts Act, presumably because of a reduction in the rate of growth of labour costs. Since inexperienced workers are typically less productive than more experienced workers, this reduces the measured average productivity of the workforce. Aggregate production, however, is likely to have increased given that more people are now in employment. Data for New Zealand compiled by Diewert and Lawrence (1999) support this interpretation. While aggregate labour productivity did not rise after 1993, this was entirely due to the expansion in the labour stock relative to capital. For a given capital-labour ratio, the New Zealand economy was in fact more productive in 1998 than in 1992.

Peetz then moves on to Australian productivity data, effectively arguing that the slowdown in productivity growth since the introduction of the Workplace Relations Act 1996 implies that individual agreements have not been beneficial for productivity. He may well be right, but might this not be because there has been relatively little uptake of AWAs? ABS data, for example, indicate that at May 2004 registered federal individual agreements (that is, AWAs) covered just 2.4 per cent of Australian employees (ABS, 2005). Moreover, a good proportion of those 
employees were not part of the 'market' sector; that is, they were working in industries where output cannot be meaningfully measured and hence not included in national productivity calculations. It is thus difficult to see how AWAs could be responsible for any significant movement in aggregate productivity given these very low rates of coverage.

A very different type of critique is provided by those who have analysed the content of AWAs (for example, Roan, Bramble and Lafferty, 2001; Mitchell and Fetter, 2003). Mitchell and Fetter (2003), for example, examined a sample of 500 AWAs finding that about half were extremely limited in their scope, making only one or two changes to the relevant award, while of the remainder the large majority were overwhelmingly concerned with pay and temporal flexibility. On the basis of this they drew the conclusion that the majority of AWAs have been focused on cost reduction rather than productivity enhancement. Gollan and Hamberger (2003), on the other hand, have argued that such evidence is largely irrelevant. They noted that AWAs are only intended to deal with pay and conditions of employment and that examining the text of agreements in an attempt to identify the presence of practices designed to promote 'high performance' workplaces is misplaced.

So how then do AWAs impact on productivity? One route is via the implementation of payment arrangements that more closely tie rewards to performance. Standard economic theory suggests that such arrangements will raise productivity by inducing greater effort and attracting more able workers (for example, Lazear 1996), and these theories have at least some empirical support performance-related pay is generally found to be associated with higher earnings (for example, Brown 1992, Booth and Frank 1999).

Very differently, Gollan and Hamberger (2003) suggest that the route to better performance is via the agreement-making process itself; that is, the direct negotiation of employment and conditions fosters a climate of common purpose and trust that is conducive to better performance. Gollan and Hamberger support their argument with survey evidence from a sample of around 1000 AWA employees and a similar sized sample of non-AWA employees, which revealed that the proportion of AWA employees who trust management (43 per cent) was considerably higher than the proportion among the non-AWA employees (34 per cent). The AWA employees also appeared to be more satisfied with the amount of control or influence they had over their work, the level of communication, workrelated training and recognition received. Such evidence, however, is still far from conclusive. At a minimum, there is a need to control for differences between the two groups. Further, there is the issue of causation. According to Wooden (1999) trust is a factor that promotes coverage by individual agreements. In other words, a high trust environment may be a precondition for acceptance of individual arrangements by workers rather than a result of the agreement-making process. Indeed, it is possible that individual agreements can be counter-productive. This might be expected if they promote competitive behaviour within workplaces and foster non-cooperative relationships, and if they are forced upon employees, as is often claimed. Such situations would tend to promote grudging performance, or 
what Williamson (1975) refers to as 'perfunctory' compliance, rather than the higher levels of performance associated with 'consummate cooperation' that is characteristic of more trusting work environments.

On balance, therefore, we are again drawn to the conclusion that we do not know whether individual agreements can improve productivity - the research needed to establish this has again not been conducted. There are, however good reasons to be wary of claims that individual agreements are a panacea for poor performance.

\section{Conclusions}

Industrial relations arrangements in Australia at the start of the $21^{\text {st }}$ century are very different from what prevailed just two to three decades earlier, with the fundamental difference being that employers and workers are generally expected to determine their own employment arrangements with far less involvement from third parties. Work Choices moves us further down the road towards selfdetermination in the workplace. Arbitration is effectively dead; awards have been rendered largely irrelevant for all but the very low paid; the role of the AIRC has been reduced to that of an industrial policeman (but who can also offer voluntary conciliation services on the side); and trade unions will find it more difficult to service their existing members, recruit new members and organize (lawful) industrial action. This legislation also clearly shifts the balance of the power in the employment relationship more towards the employer. This will be most obvious in businesses with 100 employees or less, where employers will have the right to dismiss workers almost at will. It is also reflected in the way agreements will operate. Most importantly, if offered an AWA, the only real alternative for many employees will be to quit.

Nevertheless, such a shift in the balance of power in the bargaining relationship may be a reasonable price to pay if there is a return in the form of increased employment and higher rates of productivity, as claimed by the government and most employer bodies. The tentative conclusion from this review is that jobs growth is not an unreasonable expectation, though many supporters may well be disappointed by the size of the gains. Removing wage setting powers from the AIRC to a new Australian Fair Pay Commission, for example, is unlikely to make much difference, especially to those at the bottom of the wages distribution. Ultimately, creating more competitive wage structures for low-wage workers without damaging the incentive to work requires a fusion of welfare, tax and labour market policies. Simply changing the way minimum and award wages are set will, on their own, make little difference. Exemptions from unfair dismissal laws, on the other hand, should act as a spur to increased rates of hiring, though net employment gains are likely to be concentrated among very small businesses. In the longer term, jobs growth may also be stimulated if the reforms lead to lower prices, thus stimulating consumer demand, or enable the maintenance of a more expansionary monetary policy. 
There are thus good reasons to believe that positive employment consequences are at least possible. The story with respect to productivity is far less convincing, especially given the primacy Work Choices assigns to individual agreement-making. Indeed, in the short-run it can be expected that output per worker hour will decline. This, however, will simply be a result of the expected increase in low-wage employment, and not because of any decline in the productivity of the existing workforce. The big question is whether the expected increase in use of individual agreements (both formal and informal) will be good for productivity. A priori the effects could work in either direction, and existing research provides few clues as to what the likely impact would be. Ultimately, I suspect that the impacts will depend on the way such agreements are introduced and the environment in which they are introduced. They are much more likely to be successful when introduced in cooperation with workers and in environments where there is already a high level of trust between managers and workers. On the other hand, where such agreements are forced upon workers the most likely result is higher rates of labour turnover, declining morale and grudging performance levels at best. Of course, simple economics tells us that the profit-maximising firm would not pursue this route if this were the likely outcome, but we should not under-estimate the capacity of individual managers to choose the 'easy route'. Many managers will undoubtedly be attracted to AWAs if it means not having to deal with unions and not having to worry about employee relations.

\section{References}

Abowd, J., F. Kramarz, T. Lemieux and D. Margolis (2000), 'Minimum Wages and Youth Employment in France and the United States', pp. 427-472 in D. Blanchflower and R. Freeman (eds), Youth Employment and Unemployment in Advanced Countries, University of Chicago Press, Chicago.

ACTU (2005), 'Howard Government's IR Dream Now a Living Nightmare for Working Families', Press Release, 7 December.

Australian Bureau of Statistics (2005), Employee Earnings and Hours, Australia, May 2004 (cat. no. 6306.0), ABS, Canberra.

Australian Chamber of Commerce and Industry (2005), 'Historic WorkChoices Reforms — Taking the Next Steps', ACCI Review, No. 130, December, 5-7.

Bazen, S. and N. Skourias (1997), 'Is There a Negative Effect of Minimum Wages in France?’, European Economic Review 41(3-5):723-732.

Booth, A. and J. Frank (1999), 'Earnings, Productivity, and Performance-related Pay', Journal of Labor Economics 17(July):447-462.

Brown, C. (1992), 'Wage Levels and Method of Pay', RAND Journal of Economics 23(Autumn):366-375.

Business Council of Australia (2005), Workplace Relations Action Plan for Future Prosperity, BCA, Melbourne. 
Card, D. and A. Krueger (1995), Myth and Measurement: The New Economics of the Minimum Wage, Princeton University Press, Princeton.

Daly, A., D. Nguyen-Hong, E. Eldridge, O. Gabbitas and P. McCalman (1999), Youth Wages and Employment, Productivity Commission Staff Research Paper, AusInfo, Canberra.

Diewert, E. and S. Lawrence (1999), 'Measuring New Zealand's Productivity', Treasury Working Paper 99/5, New Zealand Treasury, Wellington.

Dolado, J., F. Kramarz, S. Machin, A. Manning, D. Margolis and C. Teulings (1996), 'The Economic Impact of Minimum Wages in Europe', Economic Policy 23(October):319-370.

Freyens, B. and P. Oslington (2005), 'Dismissal Costs and their Impact on Employment: Evidence from Australian Small and Medium Enterprises', Paper presented at the Australian Labour Market Research Workshop, Australian National University, 5-6 December.

Gollan, P. and J. Hamberger (2003), 'Australian Workplace Agreements and High Performance Workplaces: A Critique of Mitchell and Fetter', Journal of Industrial Relations 45(December):521-527.

Group of 151 Australian Industrial Relations, Labour Market, and Legal Academics (2005), 'Research Evidence About the Effects of the Work Choices Bill', Submission to Inquiry into the Workplace Relations Amendment (Work Choices) Bill 2005, November.

Hamermesh, D. (1993), Labour Demand, Princeton University Press, Princeton.

Harding, D (2002), The Effect of Unfair Dismissal Laws on Small and Medium Sized Businesses, Melbourne Institute Report Series no. 2, Melbourne Institute of Applied Economic and Social Research, University of Melbourne.

Harding, D. (2005), 'Identifying and Measuring the Economic Effects of Unfair Dismissal Laws', Paper presented at the Australian Labour Market Research Workshop, Australian National University, 5-6 December.

Junankar, R., M. Waite and G. Bellchamber (2000), 'The Youth Labour Market: Anecdotes, Fables and Evidence', Economic and Labour Relations Review 11(Supplement):159-186.

Kramarz, F. and T. Phillippon (2001), 'The Impact of Differential Payroll Tax Subsidies on Minimum Wage Employment', Journal of Public Economics 82(October):115-146.

Lazear, E. (1996), 'Performance Pay and Productivity', National Bureau of Economic Research Working Paper no. 5672, NBER, Cambridge (MA).

Leigh, A. (2003), 'Employment Effects of Minimum Wages: Evidence from a QuasiExperiment', The Australian Economic Review 36(December):361-373.

Leigh, A. (2004a), 'Employment Effects of Minimum Wages: Evidence from a QuasiExperiment — Erratum’, The Australian Economic Review 37(March):102-105.

Leigh, A. (2004b), 'Minimum Wages and Employment: Reply', The Australian Economic Review 37(June):173-179. 
Lewis, P. (1985), 'Substitution Between Young and Adult Workers in Australia', Australian Economic Papers 24(June):115-126.

Loundes, J., Y. Tseng and M. Wooden (2003), 'Enterprise Bargaining and Productivity in Australia: What do we Know?’, The Economic Record 79(June):243-258.

Lye, J. and I. McDonald (2004), 'The Effectiveness of Incomes Policies, Enterprise Bargaining and Inflation Targeting in Australia', Australian Economic Papers 43(March):21-38.

Lye, J. and I. McDonald (2005), ‘Australia’s Inflation Barrier, 1965:4 to 2003:3’, Paper presented at the 34th Conference of Economists, University of Melbourne, 26-28 September.

Machin, S. and A. Manning (1997), 'Minimum Wages and Economic Outcomes in Europe’, European Economic Review 41(3-5):733-742.

Mangan, J. and J. Johnston (1999), 'Minimum Wages, Training Wages and Youth Employment’, International Journal of Social Economics 26:415-429.

Mitchell, R. and J. Fetter (2003), 'Human Resource Management and Individualisation in Australian Labour Law’, The Journal of Industrial Relations 45(September):292-325.

Peetz, D. (2005), 'Hollow Shells: The Alleged Link Between Individual Contracting and Productivity Growth’, Journal of Australian Political Economy 56(December):32-53.

Roan, A., T. Bramble and G. Lafferty (2001), 'Australian Workplace Agreements in Practice: The 'Hard' and 'Soft' Dimensions', The Journal of Industrial Relations 43(December):387-401.

Ryan, M. (2005), 'Workplace Relations Reform, Prosperity and Fairness', Australian Economic Review 38(June):201-210.

UK Low Pay Commission (2005), National Minimum Wage: Low Pay Commission Report 2005, HMSO, London.

Waring, P. and A de Ruyter (1999), 'Dismissing the Unfair Dismissal Myth', Australian Bulletin of Labour 25(September):251-274.

Watson, I. (2004), 'Minimum Wages and Employment: Comment', The Australian Economic Review 37(June):166-172.

Webster, E. (2003), 'The Effects of Wages on Aggregate Employment: A Brief Summary of Empirical Studies', The Australian Economic Review 36(March):134-142.

Williamson, O. (1975), Markets and Hierarchies, Free Press, New York.

Wooden, M. (1999), 'Individual Agreement-making in Australian Workplaces: Incidence, Trends and Features’, The Journal of Industrial Relations 41(September):417-445.

Wooden, M. (2000), The Transformation of Australian Industrial Relations, The Federation Press, Leichhardt (Sydney).

Wooden, M. (2001), 'Industrial Relations Reform in Australia: Causes, Consequences and Prospects’, The Australian Economic Review 34(September):243-262. 
Wooden, M. (2005), 'Minimum Wage Setting and the Australian Fair Pay Commission', Journal of Australian Political Economy 56(December):81-92.

The author thanks two anonymous referees for helpful comments and suggestions on an earlier draft of this paper. 